\title{
Aryl Hydrocarbon Receptor Nuclear Translocator-Like Protein 2
}

National Cancer Institute

\section{Source}

National Cancer Institute. Aryl Hydrocarbon Receptor Nuclear Translocator-Like Protein

2. NCI Thesaurus. Code C119697.

Aryl hydrocarbon receptor nuclear translocator-like protein 2 (636 aa, $71 \mathrm{kDa}$ ) is encoded by the human ARNTL2 gene. This protein plays a role in the transcriptional activation of genes involved in circadian rhythms. 